\title{
ГЕНЕЗА ДУМИ ПРО БРИТАНКУ ЮРІЯ ЯНОВСЬКОГО В КОНТЕКСТІ ТРАДИЦІЙ РАДЯНСЬКОЇ ДРАМАТУРГІЇ
}

\author{
СВІТЛАНА КОНДРАТЬЕВА \\ Інститут літератури імені Т. Шевченка НАН України, Київ - Україна \\ thorough.light@gmail.com; ORCID:0000-0003-4638-3863 \\ GENEZA DUMY O BRYTANCE JURIJA JANOWSKIEGO
W KONTEKŚCIE TRADYCJI SOWIECKIEJ DRAMATURGII \\ SWITŁANA KONDRATIEWA \\ Instytut Literatury im. Tarasa Szewczenki Narodowej Akademii Nauk Ukrainy, Kijów - Ukraina
}

STRESZCZENIE. Specyfiką tego artykułu jest uwzględnienie nie tylko ukończonego tekstu Dumy o Brytance, ale także procesu tworzenia spektaklu, który stał się możliwy dzięki obecności szkiców i notatek do utworu. Badanie jest prowadzone nie tylko w kierunku teorii literatury, ale także tekstologii. Jego trafność polega na tym, że powyższy pogląd pozwala nam zrozumieć Dumę o Brytance, i myśleć o niej, zarówno w kontekście twórczości autora, jak i ogólnie dramatu radzieckiego. Refleksja poprzedników jest ważnym czynnikiem w zrozumieniu rozwoju literatury jako procesu, w tym w kategoriach narodowych. Celem pracy jest ustalenie, jak realia czasu, a zwłaszcza przyjęty nurt literacki i wydarzenia historyczne wpłynęły na ukształtowanie się tekstu spektaklu. Wyniki badań pokazują, że jego pierwotna idea miała znacznie bardziej romantyczne cechy, ponieważ romantyzm jako styl myślenia był właściwy dla Jurija Janowskiego. Jednak w procesie tworzenia sztuki autor zaczął wykorzystywać dokumenty ukazujące prawdziwy przypadek republiki ludowej, a porzucając pierwotną wersję, stworzył sztukę będącą znacznie bliżej kanonu radzieckiego niż romantyzmu.

Słowa kluczowe: dramat, przedstawienie, Jurij Janowski, Duma o Brytance, kontekst, idea 


\title{
THE GENESIS OF YURIY YANOVSKYI'S A DUMA ABOUT BRITANKA IN THE CONTEXT OF THE SOVIET DRAMATURGICAL TRADITION
}

\author{
SVITLANA KONDRATIEVA
}

Shevchenko Institute of the National Academy of Sciences of Ukraine, Kyiv - Ukraine

\begin{abstract}
The specificity of this article is the consideration not only of the completed text entitled A Duma about Brytanka, but also of the play-forming and creating process, which became possible due to the presence of drafts and draft notes to the work. Therefore, this study is conducted not only in along the lines of literary theory, but also textology. The relevance of the study is that the view from above allows us to comprehend, or even rethink, the play A Duma about Brytanka in the context of the author's work and also in the context of the Soviet drama landscape in general. Understanding and rethinking the work of predecessors is an important process for comprehending the development of literature as a general process and its development within the national borders. The aim of the study at hand is to determine how the realities of the time and especially the accepted literary trend and historical events influenced the formation of the text of the play. The results of the study show that the original idea of A Duma about Brytanka had much more romantic features, as romanticism as a style of thinking was inherent for Yuri Yanovskyi. However, in the process of creating the play, the author began to rely on the documents that showed the real case of the social republic. The author abandoned the original version and completed the play so that it became much closer to the Soviet canon than to romanticism.
\end{abstract}

Keywords: drama, play, Yuri Yanovskyi, A Duma about Brytanka, context, idea

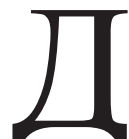

раматургічна частина доробку Юрія Яновського, зокрема, Дума про Британку, неодноразово привертала до себе увагу дослідників. В. Школа розглянула епічний характер п'єс письменника та форму вияву авторської позиції в їхній структурі, зокрема на матеріалі Думи про Британку [Школа 2017; 2014]. Ю. Котляр приділив увагу історичним аспектам твору, з'ясувавши, яке значення для творчості Яновського і власне його п’єс, мав південноукраїнський повстанський рух та як уплинули на твори письменника історичні факти, пов’язані з Висунською та Баштанською республіками [Котляр 2014; 2010]: про цей важливий вплив буде згадано і в цьому досліджені. Л. Касян розглянула аудіовізуальні документи в контексті біографiї Ю. Яновського [Касян 2017], зокрема ті, що стосувалися драматургічної частини доробку письменника. У контексті радянської драматургії розглянула п’єси Ю. Яновського Н. Кузякіна [Кузякіна 1958]. Жанрово-стильову парадигму української драматургії першої третини ХХ століття дослідила Т. Свербілова, розглянувши серед інших творів драматургічний доробок Ю. Яновського [Свербілова 2009]. Можна стверджувати, що п’єси Ю. Яновського загалом та 
Дума про Британку зокрема вже неодноразово були об'єктами дослідження: як у вужчих аспектах, так і в загальному контексті радянської драматургії. Специфікою цієї статті є розгляд не лише завершеного тексту Думи про Британку, але й процесу створення п'єси, що стало можливим завдяки наявності чернеток та нотаток до твору. Відтак, наша студія містить не лише теоретичний, а й текстологічний аспект. Подібного аналізу п’єси Ю. Яновського та його чернеток ще не було проведено, i це зумовлює наукову новизну розвідки. Актуальність дослідження полягає в тому, що вищенаведений погляд дозволяє осмислити або й переосмислити значення аналізованого твору як у вужчому контексті авторського доробку, так і в контексті радянської драматургії загалом. Метою дослідження $є$ визначення того, як прийняття соціального реалізму та інформація про реальні історичні події, зокрема появи селянських повстанських республік, вплинули на генезу тексту п’єси.

Перш ніж розглядати історію становлення Думи про Британку, необхідно прояснити певні теоретичні моменти, які важливі для цієї розвідки. Зокрема, потрібно окреслити поняття романтизму та його специфіки у межах цієї статті, остільки це поняття є досить широким і може трактуватися по-різному. Так, М. Наєнко подає у своїй праці дефініції для романтизму як трьох категорій - художнього напряму, стилю художнього мислення та стильової тональності. У контексті творчості Ю. Яновського необхідно звернути увагу на наступну з них: “романтизм як стиль художнього мислення, котрий сформувався в творчості митців романтичного світобачення, а нових ознак набув у неоромантичній літературі кінця XIX століття і в творчості окремих авторів у XX столітті" [Наєнко 2000, Вступ] - саме в цьому значенні вживає поняття романтичного щодо творчості письменника і сам М. Наєнко. Окрім визначення романтизму як стилю мислення, дослідник також називає його головну змістову ознаку: “«вилущення» героя з маси і зображення його як органічної частки індивідуалізованих особистостей” [Наєнко 2000, Розділ 2]. Основною ж рисою романтичного стилю з точки зору змісту М. Наєнко визначав прагнення ідеалу, яке для митців-романтиків “«матеріально» виявляється в відвертій настанові на перебудову життя, зумовлює всю особливість їхнього творчого процесу, характер їхнього бачення й осмислення світу" [Наєнко 2000, Вступ]. Також дослідник зазначав що для митців, схильних до романтичного стилю художнього мислення, і Ю. Яновського зокрема, було характерним “пристрасне бажання виявити в людській душі благородний, романтичний порив до краси й гармонії, передати словом той піднесений настрій людини, завдяки якому світ постійно перебудовується і вдосконалюється" [Наєнко 2000, Розділ 2]. Дослідник також зауважував особливий романтичний тип бачення дійсності, “основне в якому - максимум свободи в виявах свого творчого «я» і постійна націленість героїв на боротьбу з буденщиною, на шукання в житті його найвищого смислу. Щоб реалізувати такі художні настанови, романтики 
особливу увагу приділяють структурним питанням форми творів, ролі в них емоційно-почуттєвого елемента тощо" [Наєнко 2000, Розділ 2].

Окрім романтизму як стилю художнього мислення, притаманного Ю. Яновському, велику роль у становленні Думи про Британку зіграв також соціалістичний реалізм. Для розуміння його специфіки у цій розвідці видається достатнім обмежитися зверненням до одного з першоджерел: стенографічного звіту із першого всерадянського з'їзду радянських письменників. Там соцреалізм визначено як основний метод художньої літератури та літературної критики [Первый всесоюзный съезд... 1934: 712]. Попри формулу, наявну у Статуті Радянських Письменників СРСР про те що соціалістичний реалізм “забезпечує художній творчості виключну можливість прояву творчої ініціативи, вибору різноманітних форм, стилів і жанрів” [Первый всесоюзный съезд... 1934: 712], цей метод мав чіткі та досить жорсткі вимоги до художньої творчості. Зокрема, серед цілей радянських письменників устатуті було зазначено "правдиве зображення історії класової боротьби пролетаріату, класової боротьби та будівництва соцреалізму”, та написання творів, “насичених героїчною боротьбою міжнародного пролетаріату, пафосом перемоги соціалізму" [Первый всесоюзный съезд... 1934: 712-713]. Основний наголос при цьому робився не на правдиве зображення, а на насиченість пафосом перемоги соціалізму, що зумовлювало специфіку радянської літератури після прийняття статуту. Із наведених вище визначень стає очевидним контраст між романтичним стилем мислення та радянським методом художньої літератури - і вони обидва вплинули на становлення п'єси Ю. Яновського.

Дума про Британку, закінчена у 1937-му році, була другою п'єсою в доробку письменника, написаною одноосібно. Із самого початку автор у нотатках окреслив основу свого твору так: “П'єса про Батуринську республіку”" [Яновський б.г. Од. зб. 374: 6]. Ідея показати у п’єсі радянську республіку, яка постала під час громадянської війни, залишалася основною для драми від самого початку до кінця іiї створення. Однак іще на етапі нотаток і персонажні образи, і епізоди твору зазнали значних змін. Спочатку Ю. Яновський записав про персонажів п’єси наступне: Президент - молодий моряк (художник) і дівчина його. Будка, з якої він говорить з Москвою. а там-тільки ящик з фарбами. Він - Метелиия [Яновський б.г. Од. зб. 374:6]. Автор також зазначив, що художник скрізь (згадує) Шекспіра [Яновський б.г. Од. зб. 374: 6]. Як було зазначено вище, митцям-романтикам притаманне зображення індивідуалізованих особистостей у творах. У початковому задумі Ю. Яновський вирізняє головного героя, надаючи йому художній талант. в загальній свідомості таке обдарування сприймається як специфічна риса, яка яскраво виокремлює персонажа 3 маси. До того ж, і художник, і його дівчина зобра-

${ }^{1}$ У цитованих рукописних матеріалах тут і далі збережено правопис оригіналу. 
жені на початку їхнього життєвого і діяльного шляху, що дозволило б яскраво показати настанову героїв на перебудову життя та їхні намагання реалізувати цю настанову. Можна припустити, що Ю. Яновський втілив би це у творі, якби продовжив розробляти первісний варіант. Цікавим $\epsilon$ те, що потяг до нового життя і до майбутнього був показаний навіть через смерть головного героя у початковому варіанті фіналу: Кінець n'єси - він гине і останні слова-Здрастуй майбутнє... [Яновський б.г. Од. зб. 374: 6]. Однак персонажі 3 кінцевого варіанту п'єси дуже виразно відрізняються від романтичних героїв, окреслених вище. Головним героєм Думи про Британку став не молодий моряк і художник, а тридцятип'ятирічний революціонер Лавро Мамай, який дев'ять років і сім місяців відбув на каторзі через свої політичні погляди [Яновський 1959: 78]. Мамай не наділений художнім талантом - хоча автор і вирізняс героя, але робить це через лідерські якості персонажа. Різниця між головним героєм у нотатках та персонажем закінченого твору помітна і через прізвища: Метелиця, особливо враховуючи зменшено-пестливу форму, яскраво контрастує з прізвищем Мамай, яке відсилає до образу воїна-козака. Змінилася і кохана головного героя. Безіменна дівчина отримала ім'я Варка, і у п'єсі вона показана вже не дівчиною, а жінкою - точний вік не вказаний, але за контекстом логічно припустити, що героїня близька за віком до Лавра. У кінцевому варіанті п’єси вказано, що Варка вірно чекала Лавра $з$ каторги, але вийшла заміж за Гната Серденка, товариша Лавра, коли прийшла звістка про те, що Мамай помер. Шлюб не був щасливим: ні дітей, ні згоди - все наче Лавро посеред їхньої хати стоїть [Яновський 1959: 78], i, до того ж, в одній зі сцен кінцевого варіанту Середенко запитує: Я тебе мало бив, Варко? [Яновський 1959: 90]. На початку п’єси Середенко приїжджає до села з коханкою на ім'я Клеопатра, а Варка знову навертається до Лавра. Персонажі з кінцевого варіанту твору вже встигли отримати життєвий досвід і постраждати через власні переконання, зокрема і політичні - це особливо актуально для персонажа Лавра Мамая. Такі персонажі $є$ типовими для соцреалізму із характерним для нього зображенням боротьби пролетаріату та страждання в цій боротьбі, на відміну від персонажів з початкового варіанту, молодих, недосвідчених, що намагаються втілити в життя свою мрію про краще майбутнє.

Завдяки продовженню нотатки можна побачити різницю між початком п'єси у первісному задумі та його кінцевим варіантом. Про початок твору автор занотовував:

Ось лунають фанфари і якась героїчна мелодія розквітає перед завісою, на якій колишуться царини. Тут на сцені з'являється хата класична, він і вона.

Вона. Ну, от уяви собі, що нічого немає, зовсім нічого немає, пройшло ще стільки літ, скільки мені зараз, але мені років не побільшало, ми сидимо з тобою і задуємо минуле. (любовна сцена) [Яновський б.г. Од. зб. 374: 6]. 
Такий спокійний та ліричний початок показує пріоритетність майбутнього для героїв, їхнє бажання змінити світ, і водночас $є$ емоційно-почуттєвим елементом, яким любовна сцена не може не бути: епізод з початку п’єси у його первісному задумі був цілком романтичним. Він яскраво контрастує з кінцевим варіантом тексту: Спалена хата край степового села, коло неї-кузня, обгорілі дерева, високе небо. У с т и н з перебитою рукою. Га п к а [Яновський 1959: 77]. Устин і Гапка - мати і батько Лавра Мамая, які спостерігають за боєм загону Мамая і Середенка з денікінцями, що відбувається край села. Через їхню розмову автор показує минуле інших персонажів - Лавра, Варки і Середенка. Самі Варка і Середенко з'являються ближче до середини першої дії, а появою Лавра дія закінчується. Відтак, очевидним $€$ контраст між початком п’єси у нотатці та початком кінцевого варіанту - перший, перспективний, романтичний, показує мрії героїв; другий ретроспективний, екземпліфікує боротьбу носіїв комуністичної ідеї з представниками інших військово-політичних сил.

Говорячи про риси романтизму в початковому варіанті твору, варто зазначити що мрії персонажів про майбутнє могли з'явитися у багатьох сценах Думи про Британку. Ба більше, розглядаючи можливі назви для п’єси, автор занотував і такі варіанти як $O$, Мрія!, Мрія, Мрї та Сонще мрї [Яновський б.г. Од. 3б. 374: 6]. Мрії про майбутнє [Яновський б.г. Од. зб. 360, с. 30) занотовано як окремий пункт у чернетках Ю. Яновського, які стосуються вже пізнішого варіанту п’єси. Мрій і мрійливості у п’єсі спочатку мало бути більше, ніж залишилося у кінцевому варіанті. Автор робив до п’єси такі нотатки: Мучать Мамая, страшні тортури -мовчить, посміхається. ,Чого ти мовчиш? Про що думаєщ? ” , „Мрію” [Яновський б.г. Од. 3б. 360: 3]. Головний герой мріє не один раз: Мамай (мріє) - Мене на тачанку винесуть, коні в небо рвуться, автомат справний. Стріляй, браття... за наму мрію... За Леніна... За майбутнє... [Яновський б.г. Од. зб. 360: 6]. Автор також вигадав мрію для одного з наймолодших героїв п'єси, хлопчика Романа: Роман. ...Коли я виросту - отака моря мрія - я на ероплані полечу... [Яновський б.г. Од. зб. 361: 10]. У чернетках занотовано, що іще одному герою - Петрові Несвятипасці - треба дати широкі, гумористичні, запорізькі мрії [Яновський 1937: 3]. Однак, як уже було зазначено, до кінцевого варіанту увійшло менше згадок про мрії і епізодів з мріянням. Згадка про мрію Романа полетіти на аероплані відсутня в тексті. Немає і приміток про те, що мріє Лавро Мамай. У кінцевому варіанті п’єси цей персонаж має таку репліку: а колись, прийде час, ивістимуть вишневі садки, і така буде весна, ще ніколи в світі такої не було. За селом - ні окопів, ні колючого дроту, буде земля - тепла, пахуча, трава - шовкова, ми йдемо... За селом на могилу виходимо, а вітер, брате мій... з усього степу... з усіх світів... [Яновський 1959: 97]. Хоча прямо в тексті не сказано, що це мрія, але такий монолог цілком можна розглядати як мрію героя про щасливе майбутнє. Єдиний герой, чия мрія була оприявлена в тексті, це Петро Несвятипаска. Цікаво, що всупереч 
авторській початковій ідеї його мрія не гумористична, не має запорізького колориту, а лірична і романтична - Мрію я в театрі співати ... (Та й одійшов до вікна, засоромившись.) Отак щуоб стати й співати... а людей тисячі, усім мій голос до серия йде, і що я схочу, те з ними й роблю... Та чи вчені, а чи зовсім прості - однаково мої, та й годі... От яка мрія!.. У панського чередника, тепер - червоного партизана. Несвятипаска! - всі кричать. - Несвятипаска! [Яновський 1959: 102]. Відтак, у кінцевому варіанті твору показані лише мрії Лавра Мамая і Петра Несвятипаски, тоді як на початку роботи над п’єсою автор планував подати у тексті фантазії про майбутнє і інших персонажів, та навіть розглядав варіанти назви, які містили слово 'мрія'.

Початкові замітки про моряка-художника і його дівчину виразно відрізняються від подальших чернеток про каторжника-революціонера, з яких постав кінцевий варіант Думи про Британку. Можна припустити, що така відмінність зумовлена зверненням письменника до описів реальних історичних подій. У архіві Ю. Яновського збережено дві статті з журналу “Всесвіт", № 45 за 1927 р. Одна з них - це нарис Г. Раппепорта Висунська Народна Республіка, що описує події 1919-го року у селі Висунське на Херсонщині, яке "першим на Україні повстало й об'явило себе Селянською Народною Республікою" [Яновський 1927]. Цілком логічно, що письменник використав цей матеріал при створенні п’єси - у нарисі можна побачити імовірних прототипів героїв твору Ю. Яновського. Так, у тексті вирізки згадано Федора Савича Юхименка, старого політкаторжанина, якого було послано до Висунського для мобілізації селян у червону армію - ця постать, імовірно, стала прототипом для Лавра Мамая, чиє минуле на каторзі неодноразово згадується у п'єсі. У нарисі також указано, що Юхименко, перебуваючи в селі, керував організацією бойових дружин разом з учителем Тришевським - і в Думі про Британку також $є$ народний учитель Матвій Степанович, який входить до уряду республіки. 3 цього стає очевидним, що Ю. Яновський поступився своїм початковим романтичним задумом п'єси, натомість взявши в основу твору реальні історичні події.

Відтак, хоча Ю. Яновському був притаманний романтизм як стиль художнього мислення, що мало сильний вплив на першопочатковий задум Думи про Британку, однак автор змушений був враховувати вимоги соцреалізму та звернувся до історичних джерел, взявши їх за основу твору. Перші начерки до п’єси мали виразні романтичні риси - молоді герої, що прагнуть кращого майбутнього, головний персонаж вирізнений з маси через художній талант, лірично-емоційний початок п’єси. Навіть у пізнішому варіанті твору Ю. Яновський планував показати мрії персонажів, виразивши через це спрямованість їхніх думок до кращого життя, до майбутнього. Однак автор мав також брати до уваги вимоги соцреалізму як загальноприйнятого тоді методу мистецтва на радянських теренах. Ю. Яновський звернувся до матеріалів, які описували реальне постання Селянської Народної Республіки, і відмовився від своєї почат- 
кової романтичної ідеї, поклавши в основу твору реальні події. Ця специфічна ситуація безумовно вплинула на генезу Думи про Британку, через що кінцевий варіант твору став набагато ближчим до традиції радянської літератури, ніж до романтизму як притаманного письменникові стилю художнього мислення.

\section{Список використаної літератури}

Касян Л., Аудіовізуальні документи в контексті автобіографічного синергену Юрія Яновського, [в:] „Архіви України”, 2017, № 3-4, с. 156-168.

Котляр В., Вплив Висунської і Баштанської республік на літературу і мистеитво України, [в:] „Чорноморський літопис", 2010, вип. 1, с. 51-55.

Котляр В., Південноукраӥнське повстанство у творчості Юрія Яновського, [в:] „Наукові праці Чорноморського державного університету імені Петра Могили. Серія: Історія”, 2016, вип. 262, с. 12-16.

Кузякіна Н., Нариси української радянської драматургії. Частина 1 (1917-1934), Київ: Радянський письменник, 1958.

Наєнко М., Вступ. Романтичний епос: ефект романтизму і украӥнська література, Київ: Просвіта, 2000, [в:] Електронний ресурс: http://ukrlife.org/main/prosvita/eposvstup.htm. (15.10.2020).

Наєнко М., Розділ 2. Романтичний епос: ефект романтизму і украӥнська література, Київ: Просвіта, 2000, [в:] Електронний ресурс: http://ukrlife.org/main/prosvita/epos2. htm (15.10.2020).

Первый всесоюзньй съезд советских писателей 1934: Стенографический отчет, Москва: Советский писатель, 1990.

Свербілова Т., Від модерну до авангарду: жанрово-стильова парадигма украйнської драматургї першої третини ХХ століття, Ін-т літератури ім. Т.Г. Шевченка НАН України: Черкаси 2009.

Школа В., Епічний характер n'єс Юрія Яновського, [в:] „Наукові записки Бердянського державного педагогічного університету. Сер.: Філологічні науки”, 2014, вип. 2, с. 108-118.

Школа В., Форма вияву авторської позииї в структурі п'єс Юрія Яновського та Олександра Довженка, [в:] „Наукові записки Бердянського державного педагогічного університету. Сер.: Філологічні науки”, 2017, вип. 12, с. 82-87.

\section{Spysok vykorystanoi literatury [References]}

Kasian L., Audiovizualni dokumenty v konteksti avtobiohrafichnoho synerhenu Yuriia Yanovskoho [Audiovisual documents in the context of Yuri Yanovsky's autobiographical synergy], [v:] „Arkhivy Ukrainy”, 2017, № 3-4, s. 156-168. 
Kotliar V., Vplyv Vysunskoi i Bashtanskoi respublik na literaturu i mystetstvo Ukrainy [The influence of the Vysun and Bashtan republics on the literature and art of Ukraine], [v:] „Chornomorskyi litopys”, 2010, vyp. 1, s. 51-55.

Kotliar V., Pivdennoukrainske povstanstvo u tvorchosti Yuriia Yanovskoho [South Ukrainian uprising in the works of Yuri Yanovsky], [v:] „Naukovi pratsi Chornomorskoho derzhavnoho universytetu imeni Petra Mohyly. Seriia: Istoriia”, 2016, t. 274, vyp. 262, s. 12-16.

Kuziakina N., Narysy ukrainskoi radianskoi dramaturhii. Chastyna 1 (1917-1934) [Essays on Ukrainian Soviet drama. Part 1 (1917-1934)], Kyiv: Radianskyi pysmennyk, 1958.

Naienko M., Vstup. Romantychnyi epos: efekt romantyzmu i ukrainska literatura [Romantic epic: the effect of romanticism and Ukrainian literature], Kyiv: Prosvita, 2000, [v:] Elektronnyi resurs: http://ukrlife.org/main/prosvita/eposvstup.htm (15.10.2020).

Naienko M., Rozdil 2, Romantychnyi epos: efekt romantyzmu i ukrainska literatura. [Romantic epic: the effect of romanticism and Ukrainian literature], Kyiv: Prosvita, 2000, [v:] Elektronnyi resurs: http://ukrlife.org/main/prosvita/epos2.htm (15.10.2020).

Pervyi vsesoiuznyi sezd sovetskikh pisatelei 1934: Stenograficheskii otchet [First All-Union Congress of Soviet Writers 1934: Verbatim Report], Moskva: Sovetskii pisatel, 1990.

Sverbilova T., Vid modernu do avanhardu: zhanrovo-stylova paradyhma ukrainskoi dramaturhii pershoi tretyny KhKh stolittia [From Art Nouveau to the Avant-Garde: Genre and Style Paradigm of Ukrainian Drama of the First Third of the 20th Century], In-t literatury im. T.H. Shevchenka NAN Ukrainy, Cherkasy, 2009.

Shkola V., Epichnyi kharakter pies Yuriia Yanovskoho [The epic nature of Yuri Yanovsky's plays], [v:] „Naukovi zapysky Berdianskoho derzhavnoho pedahohichnoho universytetu, Ser. Filolohichni nauky", 2014, vyp. 2, s. 108-118.

Shkola V., Forma vyiavu avtorskoi pozytsii v strukturi pies Yuriia Yanovskoho ta Oleksandra Dovzhenka [The form of expression of the author's position in the structure of plays by Yuri Yanovsky and Alexander Dovzhenko], [v:] „Naukovi zapysky Berdianskoho derzhavnoho pedahohichnoho universytetu. Ser. : Filolohichni nauky”, 2017, vyp. 12, s. 82-87.

\section{Список використаних джерел}

Яновський Ю. 1927 [ «Висунська Народна Республіка»-нарис, який ліг в основу n'єси Ю. Яновського «Дума про Британку»], Київ: Відділ рукописних фондів і текстології Інституту літератури ім. Т.Г. Шевченка НАН України. Фонд 116, од. зб. 394.

Яновський Ю. б.г. [“Дума про Британку» - план, замітки та уривки чорнової редакиії IIIої діï n'єcu], Київ: Відділ рукописних фондів і текстології Інституту літератури ім. Т.Г. Шевченка НАН України. Фонд 116, од. зб. 360.

Яновський Ю. 1937 [“Дума про Британку» - поправки і додатки до основного тексту n'єcu], Київ: Відділ рукописних фондів і текстології Інституту літератури ім. Т.Г. Шевченка НАН України. Фонд 116, од. зб. 363.

Яновський Ю. б.г. [«Дума про Британку» - розробка назви драми], Київ: Відділ рукописних фондів і текстології Інституту літератури ім. Т.Г. Шевченка НАН України. Фонд 116, од. зб. 374. 
Яновський Ю. б.г. [ Дума про Британку» - чорнові матеріали до IIІої дї̈ n’єси (плани, начерки, варіанти початку акту та 2ої картин)], Київ: Відділ рукописних фондів і текстології Інституту літератури ім. Т.Г. Шевченка НАН України. Фонд 116. од. зб. 361.

Яновський Ю. Твори в n'яти томах. Том 3, Київ: Державне видавництво художньої літератури, 1959.

\section{Spysok vykorystanykh dzherel [References]}

Yanovskyi Yu. 1927 ["Vysunska Narodna Respublika»-narys, yakyi lih v osnovu piesy Yu. Yanovskoho "Duma pro Brytanku»]. ["Vysunska Social Republic" - an essay that formed the basis of the play by Y. Yanovsky "Duma of Britanka”], Kyiv: Viddil rukopysnykh fondiv i tekstolohii Instytutu literatury im. T.H. Shevchenka NAN Ukrainy. Fond 116, od. zb. 394.

Yanovskyi Yu. b.h. ["Duma pro Brytanku» - plan, zamitky ta uryvky chornovoi redaktsii IIIoi dii piesy]. ["Duma of Britanka" - plan, notes, and fragments of draft edition of III act of the play], Kyiv: Viddil rukopysnykh fondiv i tekstolohii Instytutu literatury im. T.H. Shevchenka NAN Ukrainy. Fond 116, od. zb. 360.

Yanovskyi Yu. 1937 [ «Duma pro Brytanku»-popravky i dodatky do osnovnoho tekstu piesy]. ["Duma of Britanka" - correction and additions to the main text of play], Kyiv: Viddil rukopysnykh fondiv i tekstolohii Instytutu literatury im. T.H. Shevchenka NAN Ukrainy. Fond 116, od. zb. 363.

Yanovskyi Yu. b.h. ["Duma pro Brytanku» - rozrobka nazvy dramy]. ["Duma of Britanka”the development of the title of the drama]. Kyiv: Viddil rukopysnykh fondiv i tekstolohii Instytutu literatury im. T.H. Shevchenka NAN Ukrainy. Fond 116, od. zb. 374.

Yanovskyi Yu. b.h. [«Duma pro Brytanku» - chornovi materialy do IIIoi dii piesy (plany, nacherky, varianty pochatku aktu ta 2oi kartyn)]. ["Duma of Britanka" - drafts for III act of play (plans, notes, variants of the beninning of act and 2 scene)]. Kyiv: Viddil rukopysnykh fondiv i tekstolohii Instytutu literatury im. T.H. Shevchenka NAN Ukrainy. Fond 116, od. zb. 361.

Yanovskyi Yu. Tvory v piaty tomakh. [Works in five volumes]. Vol 3, Kyiv: Derzhavne vydavnytstvo khudozhnoi literatury, 1959. 